\title{
Editorial to the special issue in memory of Jean-Pierre Huiban
}

\author{
Carl Gaigné $^{1} \cdot$ Bertrand Schmitt $^{2} \cdot$ Patrick Sevestre $^{3} \cdot$ Michel Simioni $^{4}$
}

Published online: 19 September 2016

(C) INRA and Springer-Verlag France 2016

This special issue of the Review of Agricultural, Food and Environmental Studies (RAFE) is dedicated to the memory of Jean-Pierre Huiban who passed away prematurely on 16 June 2013 at the age of 58 (he was born on 9 September 1954 in Ivry-sur-Seine, France). This follows the conference organised by INRA in his honour and memory on 27 January 2015. Jean-Pierre Huiban was a well-known and much-appreciated senior research fellow (Directeur de Recherche) at INRA, the French National Institute for Agricultural Research, where he had worked since 1985.

After obtaining a Master's degree in economics from the University of Paris-Dauphine in 1977, Jean-Pierre took a $\mathrm{PhD}$ degree at the same university under the supervision of Xavier Greffe and Jacques Delors, the future French Minister of Economy and Finance (1981-1984) and future President of the European Commission (1985-1995). Jean-Pierre's PhD thesis, defended in 1981, focused on proposals for drawing up industrial policies to improve the growth and competitiveness of French manufacturing industries. After 2 years in a post-doctoral position at the same research centre (Travail et Société, University of Paris-Dauphine), Jean-Pierre worked as a researcher in economics with a French think tank linked to the national labour unions, where he developed his work in the field of labour economics

Carl Gaigné

carl.gaigne@inra.fr

1 INRA, UMR SMART, 4 allée Adolphe Bobierre, CS61103, 35011 Rennes cedex, France

2 DEPE, INRA, 21065 Dijon, France

3 GREQAM, Université Aix-Marseille, 13002 Marseille, France

4 MOISA, INRA, 34060 Montpellier, France
(1982-1985). He then became a research fellow (Chargé de Recherche) with INRA at the research unit in Lille, studying the determinants of competitiveness and the dynamics of the food industry. He headed this research unit from 1992 to 1999 before moving from Lille to Dijon, where he worked at the CESAER research unit (Centre d'Ecomomie et de Sociologie appliquées à l'Agriculture et aux Espaces Ruraux). He introduced spatial issues into his analyses of the food industry and became deputy head of the CESAER research unit from 2002 to 2006. He was also associate professor at the University Paris-XII and associate researcher at the ERUDITE research unit (Equipe de Recherche sur l'Utilisation des Données Individuelles en lien avec la Théorie Economique) where he became a talented applied econometrician. In 2009, after 10 years in Dijon, he decided to join another INRA research unit, ALISS (Alimentation et Sciences Sociales) in Paris. His research then examined innovation and environmental issues and their impacts on food industry competitiveness.

Throughout his career, Jean-Pierre published a significant number of papers in international academic journals such as Applied Economics, Industrial and Corporate Change, Small Business Economics, Journal of Productivity Analysis, Growth and Change, and Environment and Planning $A$ as well as French journals such as Annales d'Economie et de Statistique, Economie et Prévision, Economie Rurale, and Revue Economique, and, last but not least, in RAFE when it was still known as the Review of Agricultural and Environmental Studies.

Jean-Pierre's earliest articles focused on employment in the food industries (Huiban, 1990) and the impact of skilled labour on productivity, either as such (Huiban, 1994) or in association with innovation (Huiban and Bouhsina, 1997a). He soon turned to his two main fields of research: innovation and firms' survival and demography. As a follow-up to his earliest papers, he devoted much of his attention first to the impact of skilled labour on innovation (Huiban and Bouhsina, 1997b, 1998) and then to 
firms' propensity to innovate, looking at the determinants of innovation in knowledge-intensive business services sectors (Huiban and Musolesi, 2010) or corporate groups (Blanchard, Huiban and Sevestre, 2005) as well as examining obstacles to innovation (Blanchard, Huiban, Musolesi and Sevestre, 2013).

His interest for the issue of firms' survival grew from his indepth study comparing trends in employment and firms' demography in rural and urban areas (Huiban, Aubert and Mariettaz, 2002; Huiban, 2003; Huiban, Détang-Dessendre and Aubert, 2004; Huiban, Aubert and Dussol, 2006, 2007; Huiban, 2009). He then moved to a more microeconomic approach of firms' survival (Huiban, 2011; Blanchard, Huiban, Mathieu, 2012, 2014). The first article of this special issue (Aleksanyan and Huiban, 2016) follows in the footsteps of his recent papers on firms' survival.

Beyond these two main areas of research, Jean-Pierre Huiban also made contributions to questions such as gender inequalities in wage mobility (Berton, Huiban and Nortier-Ribory, 2009a, 2009b, 2011, 2013), and, more recently, the impact of pollution abatement investments on firm performance (Huiban, Mastromarco, Musolesi and Simioni, 2015). In the latter paper, the authors show that the so-called Porter's Hypothesis (i.e. that properly-designed environmental regulations may have beneficial effects on firms' productivity) may hold in some instances.

It is not easy to summarise Jean-Pierre's abundant research, but two distinctive features can be clearly identified. Firstly, his research was certainly not merely academic and was inspired by some of the most important issues that our economies and societies currently face: employment developments, the propensity to innovate, economic activity in rural areas, and the environment. The significance of these issues in France and many other countries does not need to be pointed out. It is striking that Jean-Pierre started working on those questions well before they became fashionable "hot topics".

The second important characteristic of Jean-Pierre's work is its impact on our research community. The most obvious way to assess this impact can be seen in the numerous citations of his articles and working papers. As shown by $R e P E c$, his work is frequently quoted by researchers not only in France but also abroad, and not only by researchers working in agricultural economics. Although Jean-Pierre's research often focused on rural areas and food industries, he always held the view - and was able to convince his readers - that the issues he addressed were also relevant for other sectors of the economy, despite the specificities of these sectors. Another more indirect but probably more important impact of Jean-Pierre's research on our community is the "research education" he provided for many young (and not so young) researchers during his career. Several authors of the papers included in this special issue fall under this "category".

These two characteristics of his work are reflected in the contents of this special issue. The first article, entitled "Economic and Financial Determinants of Firm Bankruptcy: Evidence from the French Food Industry" is, at the time of writing, Jean-Pierre's last published article. In it, he and Lilia Aleksanyan (formerly a PhD student whom he co-supervised) examine the economic and financial determinants of firm exits owing to bankruptcy in the French food industry and compare them with those from other manufacturing industries. The French food industry suffered less than other industries during the "great" financial crisis of 2008-2009, but faced greater difficulties later, from 2011 onwards. Based on a large sample of firm-level data for the period 2001-2012, they show that the bankruptcy risk pattern differs between food industry firms and other manufacturing firms. They also show that firms' productivity is an important determinant of their probability of going bankrupt. In particular, firms going bankrupt see their productivity deteriorating for 3 years before their failure. They also highlight the impact of the cost of credit on the probability of bankruptcy. However, firm financing conditions have a lesser effect on bankruptcy than their productivity.

The second paper, entitled "Multinationals and domestic firms in France: who gains from knowledge spillovers?", also addresses a question that Jean-Pierre studied closely. Pierre Blanchard and Claude Mathieu, the two authors of this article, as well as many other colleagues, can testify to the long discussions they had with Jean-Pierre about the difficulties in measuring and interpreting knowledge spillovers. In this paper, Blanchard and Mathieu assess the direction, nature and magnitude of spillovers between foreign-owned firms and French firms. Using a large firm-level panel dataset, they estimate production functions using the econometric techniques suggested in Ackerberg, Caves and Frazer (2006). Three main conclusions can be drawn from their estimations. Firstly, spillovers exist in all research-intensive sectors, but their impact is lower in less knowledge-based sectors. Secondly, subsidiaries of foreign multinational firms active in high- and medium-technology manufacturing industries benefit from horizontal spillovers. Thirdly, inward foreign investment contributes to increasing the total productivity factor of French firms that supply inputs to multinationals (backward spillovers). However, this effect only exists in high- and medium-technology manufacturing industries and takes some time to emerge.

As mentioned above, the last working paper written by JeanPierre, together with Camilla Mastromarco, Antonio Musolesi and Michel Simioni (Huiban, Mastromarco, Musolesi and Simioni, 2015), deals with the so-called "Porter Hypothesis", i.e. the idea that well-designed regulations and standards may, contrary to the common view, have positive effects on firms and the economy as a whole. This seemingly paradoxical hypothesis is also at the core of the third article in this special issue. In this article, "The Agro-Food Industry, Public Health and Environmental Protection: the Porter Hypothesis to Justify Regulation?", Eric Giraud-Héraut, JeanPierre Ponssard, Bernard Sinclair-Desgagné and Louis-Georges Soler argue that the regulation of food products may have positive effects, not only on consumers, but also on food firms and the 
economy as a whole. After a general presentation of this hypothesis, the authors provide a more in-depth discussion of its relevance regarding nutritional issues. Whilst organisational imperfections and market failures are often advocated for validating the Porter Hypothesis, Giraud-Héraut, Ponssard, Sinclair-Desgagné and Soler consider another rationale based on consumer behaviour. With regard to nutritional issues, many empirical studies show that some consumers consider that healthy products are less tasty due to their limited salt or fat content. These consumers may then be reluctant to buy these products even though they would be better for their health. The authors show that under this assumption, firms cannot unilaterally commit to improving product (health) quality. Public regulation is then required to encourage an implicit coordination between firms in order to improve average product quality.

In the fourth and final article of this special issue, entitled "Public Quality Standards and the Food Industry's Structure in a Global Economy", Carl Gaigné and Bruno Larue study the impact of public quality standards on firm entry/exit, market structure and welfare, in a context of international trade. This paper is complementary to work led by Jean-Pierre in two research areas: the determinants of exit/entry and the impact of public regulation on firm performance in the food industry. Gaigné and Larue address these two questions simultaneously in a unified framework. They develop an international trade model with vertical differentiation based on monopolistic competition in which firms differ in terms of their productivity and incur two fixed export costs when exporting to any given destination: a generic one, i.e. setting up a distribution system, and a destination-specific one to meet the quality standards in place in the importing country. Variable costs also increase with quality. The absolute mass of firms in any given country is lowering domestic standards, but the relative (market share) mass of foreign firms is raising domestic standards. Higher public quality standards benefit highly productive foreign firms that gain from the quality-induced exit of less productive firms. The increase in industry productivity following stricter public standards is not a result of induced innovation as in the Porter Hypothesis, but of the exit of less productive firms.

It would be impossible to conclude this introduction without mentioning that, in addition to his very impressive research career and all that he passed on to those working with him, Jean-Pierre was a fantastic person. In short, he was a person you liked when you met him for the first time, whom you were eager to meet a second time and who definitely became a close friend after that. He is sorely missed. We would like to thank the RAFE for giving us the opportunity to put together this special issue to pay tribute to Jean-Pierre Huiban as he deserved.

\section{References}

Ackerberg D., Caves K., Frazer G. (2006). Structural identification of production functions, Working paper $\mathrm{n}^{\circ} 38349$, UCLA, $43 \mathrm{p}$.
Aleksanyan L., Huiban J.-P. (2016). Economic and financial determinants of firm bankruptcy: evidence from the French Food Industry, Review of Agricultural, Food and Environmental Studies, (infra).

Berton F., Huiban J.-P., Nortier-Ribory F. (2009a). Long run French careers in the private sector: women's vs. men's, Communication to Society for the Advancement of Socio-economics (21st annual conference), Paris, July 16-18, $17 \mathrm{p}$.

Berton F., Huiban J.-P., Nortier-Ribory F. (2009b). Les carrières salariales françaises du privé: génération 1962 versus génération 1946, in: Perez C., Divay S. \& Outin J.-L. (eds) Cheminements longs : données, méthodes et apports pour les analyses du marché du travail, CEREQ, Relief, 29: 327-345.

Berton F, Huiban J-P, Nortier-Ribory F (2011) Les carrières salariales des hommes et des femmes : quelle convergence sur longue période? Travail et Emploi 125:9-25

Berton F., Huiban J.-P., Nortier-Ribory F. (2013). Have male and female careers converged?, Travail et Emploi, 2013/5 (HS 2013): 99-114.

Blanchard P, Huiban J-P, Mathieu C (2012) The determinants of firm exit in the French food industries. Review of Agricultural and Environmental Studies 93(2):193-212

Blanchard P, Huiban J-P, Mathieu C (2014) The shadow of death model revisited with an application to French firms. Appl Econ 46(16): 1883-1893

Blanchard P, Huiban J-P, Musolesi A, Sevestre P (2013) Where there is a will, there is a way? Assessing the impact of obstacles to innovation. Ind Corp Chang 22(3):679-710

Blanchard P, Huiban J-P, Sevestre P (2005) R\&D and productivity in corporate groups: an empirical investigation using a panel of French firms. Annals of Economics and Statistics 79-80:461-485

Huiban J-P (1990) L'emploi salarié dans les industries agro-alimentaires. Économie rurale 198(1):40-40

Huiban J-P (1994) La relation entre la qualité du facteur travail et son efficacité productive. Économie et Prévision 116(5):63-78

Huiban J.-P. (2003). Entreprises et activités industrielles en milieu non urbain. Bilan et perspectives, INRA Sciences Sociales.

Huiban J-P (2009) Urban versus rural firms: does location affect labor demand? Growth and Change 40(4):649-672

Huiban J-P (2011) The spatial demography of new plants: urban creation and rural survival. Small Bus Econ 37(1):73-86

Huiban J-P, Bouhsina Z (1997a) Innovation, qualité du facteur travail et efficacité productive. Revue Économique 48(3):605-614

Huiban J-P, Bouhsina Z (1997b) Innovation et qualité du facteur travail. Cahiers d'Economie et Sociologie Rurales 44:107-137

Huiban J-P, Bouhsina Z (1998) Innovation and the quality of labour factor: an empirical investigation in the French food industry. Small Bus Econ 10(4):389-400

Huiban J-P, Musolesi A (2010) Innovation and productivity in knowledge intensive business services. J Prod Anal 34(1):63-81

Huiban J-P, Aubert F, Dussol A-M (2006) La démographie des établissements industriels : une différenciation entre espaces urbains, périurbains et ruraux. Revue d'économie régionale et urbaine 2006(5):751-779

Huiban J.-P., Aubert F., Dussol A.-M. (2007). Démographie d'entreprises : des créations plus fréquentes en zone urbaine, plus durables en zone rurale, INRA Sciences Sociales.

Huiban J-P, Aubert F, Mariettaz J (2002) De l'urbain vers le rural : les transferts d'établissements de l'agro-alimentaire. Revue d'économie régionale et urbaine 2002(3):423-447

Huiban J-P, Détang-Dessendre C, Aubert F (2004) Urban versus rural firms: is there a spatial heterogeneity of labour demand? Environment and Planning A 36(11):2033-2045

Huiban J-P, Mastromarco C, Musolesi A, Simioni M (2015) The impact of pollution abatement investments on technology: Porter hypothesis revisited, in: Working papers 2015084. Department of Economics, University of Ferrara, Italy 